\title{
Spacing and Places Arrangements: A Study of the Identity Symbols of Moto Club "Children of Freedom" and Their Representations
}

\author{
Eliana do Pilar Rocha ${ }^{1}$ \\ ${ }^{1}$ Claretiano - Centro Universitario, Brazil \\ *Corresponding author: Eliana do Pilar Rocha: elianarocha.ane@gmail.com
}

Citation: Rocha E.P. (2021) Spacing and Places Arrangements: A Study of the Identity Symbols of Moto Club "Children of Freedom" and Their Representations. Open Science Journal 6(1)

\section{Received: $30^{\text {th }}$ August 2020}

Accepted: $27^{\text {th }}$ October 2020

Published: $1^{\text {st }}$ February 2021

Copyright: (C) 2021 This is an open access article under the terms of the Creative Commons Attribution License, which permits unrestricted use, distribution, and reproduction in any medium, provided the original author and source are credited.

Funding: The author(s) received no specific funding for this work

Competing Interests: The author has declared that no competing interests exists.

\section{Abstract:}

The article is the result of an ethnography carried out on a motorcycle club located in the city of Curitiba, Brazil, called the Brotherhood Children of Freedom, and seeks to understand how the members of the motorcycle club construct the category of place in different micro spaces through their greater symbols, such as the brotherhood headquarters, the badge in their vests and the trips through the roads under formation. The city is considered as a field of analysis, from the overlapping spaces and plurality individual group. In this context, it describes the identity constructions among the Brotherhood's members, their obligations and restrictions in new arrangements related to those appropriate spaces and transformed into place. It also shows how, in relations with others inside or outside the city, spaces of different scales are appropriate by the members of the Brotherhood by means of their symbols, values, beliefs and identity, to which systems of significance are attributed, such as the very notion of belonging and tradition of the Brotherhood Children of Freedom.

Keywords: Motor club, City, Space, Place, Symbols, Identity, Tradition 


\section{Introduction}

\section{City, place, space and identity}

By definition, the term 'place' refers to numerous interpretations. Some of them may be under the epistemological concepts of the social and human sciences, others presented from the singularities of a society, group or culture. In this work, the fruit of empirical observation, one seeks to understand the place as a descriptive category, which emerges as interpreted starting from the deconstruction of conceptual categories and reconstructed from the articulation of new symbolic categories of appropriation, constructions and experiences.

Menezes [1] explains that it is relevant to consider the place through a relational perspective that, by projecting socio-spatial reality and serving as a locus for the observation of the phenomena that constitute this reality, provides tools for the knowledge of relationships.

As a group is constituted and maintained in a place and time by the construction of its identity, cultural dynamics and traditionality, this article describes the recording of observations, informal conversations, behaviors, practices, feelings, habits, gestures and expressions that are translated into social representations linked to the customs of members of a motorcyclist group called the Children of Freedom Brotherhood.

Lopes apud Martins [2] states that motorcycling is a complex and gigantic universe, involving many stereotypes. In addition, he adds: "many consider it an addiction and a way of life".

For this author, when we think about these social groups, we have to address a series of categories that are part of this universe, with their interpretation linked to the relationships of people, individuals and those subject to the dynamics that allow us to seize their records, such as the very manifestation of their consciousness, the rational motivations of action or the constitution of places.

It was assumed that even though the city is a place of plurality, of coexisting differences and of exacerbation of the individual, not all of those who live in it choose to merge themselves into the multiple and live as an anonymous homogenous. People who live in cosmopolitan diversity and overlap have been sought, people who can move between two worlds, from the individual and the group, conforming to Moura [3].

As this study develops in the urban environment, we will approach Urban Anthropology and its look at the city as a space of multiple occupied heterogeneous territories, whether used or not, and their urban groups, always in alternate conditions of contradictions and completions. Or otherwise, from the cities within the city, according to Uriarte [4].

The author also proposes that 'urban space anthropology' be referred to as the area of study that is interested in the production of spaces in the city by ordinary people, in contrast to studies of micro-spaces produced by abstract forces, such as the market or real estate capital [4]. From this point of view, we see the city as a set of multiple spaces differentiated between them that make up and divide, floating between contradictory and complementary relationships.

While Fortuna [5] demonstrates that it's possible to analyze the territorialities in their micro scale, if observed at between the socio-spatial processes of the macro and micro scale. Thus, spatialities resulting from the current urban 
continuities, market cycles, sociopolitical processes and rhythms of urban life are not discarded, but they are observed from the sensitive universe of the social and its micro events, their spatial representations and appropriations arising of memories, identities, senses, symbols and affectivities.

Velho \& Kuschnir [6] explains that is possible to study the individuals in their uniqueness if we observe them as subjects of some social action that have been woven from a certain network of meanings.

"Instead of considering individuals as determined by previous encompassing instances, they are being studied as map interpreters and sociocultural codes, emphasizing a dynamic view of society and seeking to establish bridges between the micro and macro levels". [6]

And it is precisely this quality of giving identity expressions that assigns the social and human character to these places and therefore gives them, in their social nature, the multiplicity that we seek to understand here.

Space Anthropology is interested in the space lived, in the way the usersinhabitants-occupiers experience these spaces, states Ségaud [7]. Space is treated here, not as a center of concern, but as a context of interactions. It is that space identified by history, defined by the human presence of its identities and symbols, that is the space transformed, from its specificities, into place.

So what is meant to be demonstrated here are the relationships established in different small-scale spaces, by men who have in common motorcycling as a lifestyle, which gives them, through the human and social expression developed there and perpetuated in outer space, their spatial definition and particular territorial dimension, mainly through their symbols and expressions of identities or, otherwise, their place.

It also seeks to demonstrate how this same place can be recreated from the demarcation of subjects and their symbols in non-material places, in a new identity dimension.

To this end, the intention is to start putting the subject into context from a brief description of the history of motorclubs in North America, and then a reading of how they are established in Brazil after World War II. Later on, it should show the genesis of motor clubs in Brazil. So we'll dive into the universe of the motor club under study.

When choosing as a research object the micro spatialization of the Children of Freedom Brotherhood and its construction and inscription in spaces that are sometimes printed in territorialities without precise borders, the need arose for the object (territory) to be adapted to study (anthropological place).

As we have already mentioned in this article, and in the light of Fortuna [5], the Brotherhood was analyzed as a micro territoriality, that is, in the representation that space symbolizes when it demonstrates a set of consistent relations existing in the subjectivities that space itself occupied by them can represent.

We therefore intend to analyze how the Brotherhood's micro-territories are maintained, viewed in this work as places, because they are a fraction of the space that is established around values, symbols, and subjectivities. It seeks to understand the ways of extending this place, outside the headquarters of the motor club, from road exits by train, or from participating in parties and meetings of national and international motor clubs, as well as within-city movements, visits to other motor clubs, and meetings at bars and concerts promoted to and from the category. 
It's important to understand what rules and behaviors are required of Brotherhood members, in their obligations and restrictions they assume when carrying the motor club badge, in their vest, outside their headquarters.

Given that Brazil is South America's largest country and has been colonized by the Portuguese with a focus on exploiting its natural resources, it has, since the sixteenth century, exhibited great cultural diversity, since it has always opened its borders to all peoples who wanted to establish themselves here. This is shown today, among its approximately 209 million inhabitants, different cultures and historicities living side by side.

This cultural diversity has enabled the construction of a country of different arrangements, meanings, and social categories, which allows for a reading of the different senses and symbols they present, among their nearly 209 million residents. The study considered, in addition to Curitiba, other capitals such as Goiânia in the Central West, Recife and Salvador, in the Northeast region of the country. That's because there's a multitude of habits, rites, myths, and traditions spread across the country (Picture 1).

\section{Map of Brazil: study areas and mentioned areas}

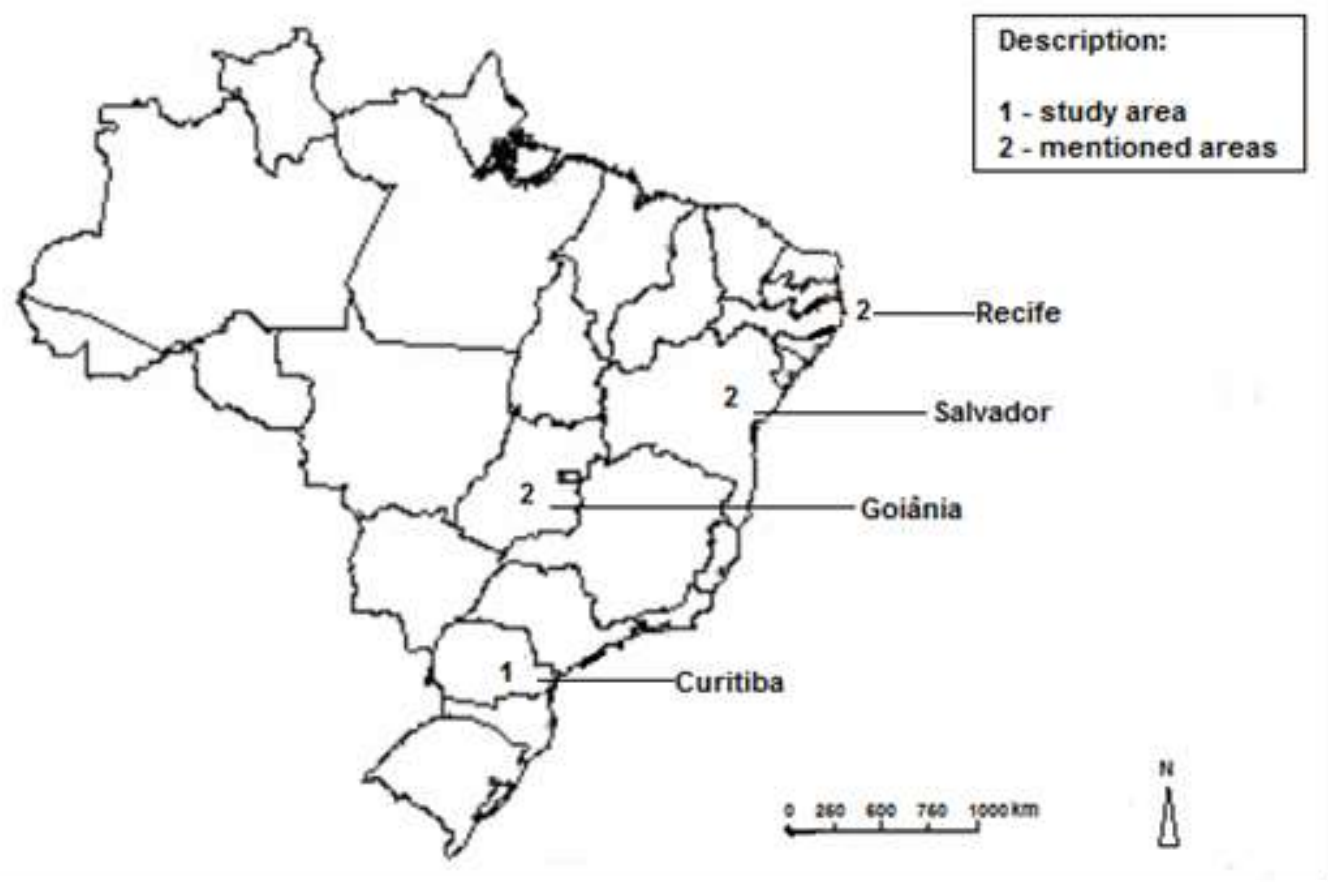

Picture 1: Map of Brazil: study areas and mentioned areas (Made by author)

Work has been sought specifically to address the search for interpretations of certain aspects relating to motorcycle club spacialities, urban tribes and counterculture.

Based on the works analyzed and field research, this article describes the group under study, based on its main symbols, what they are: the headquarters of the motorcycle club, the badge and the train, and its spatial dimension. This dimension, which can be observed by a multitude of meanings and senses, operates, generally, within micro-territories in cities, small portions of the space visibly identified to which, in this work, we call the place. 


\section{Methodology}

\section{Anthropologists and their methods and research techniques}

This article results from a survey conducted between March and August 2018, and has been constructed though observations from visits to the headquarters of a group of motorcyclists based in the city of Curitiba, Paraná, whose entity is called Brotherhood Children of Freedom.

Founded in October 1997 with just three members, the intention was to start a group that had its own identity and that brought together people who expressed the same interests. With the motorcycle as its main link, as a basis for trust, as a structure for respect and as a common interest, exchanges and values in relation to society and the environment, officially adopted the date of January 10, 1998 as the start of the Children of Freedom Brotherhood.

Notes were made during the meetings of associates who are always on Thursdays at night, and the notes were from informal conversations with group members, guests and visitors, and interpretation of symbols, speeches, and other aspects.

Considering the objectives of the work, the method of participating observation proved to be satisfactory, as it results in the articulation of partial information with direct observation, participating in the day to day and interpreting the facts and interlines of speeches by members, guests and visitors. We are therefore concerned with drawing up a summary of the procedures for organizing and reorganizing representations in social practice.

Based on the understanding of these permanent processes, we seek to separate them from the stories and trajectories of other groups of motorcyclists, who precede them in studies of a complex nature of lives in metropolises, as can be observed throughout the text.

The work with the field book, even if appears to be averse to the possibilities arising from the currently available technology, allows the researcher to observe more subjectivities, or to see other experiences that are experienced by the anthropologist in the field. This is what Roberto Cardoso de Oliveira [8] calls the strategic moment of the anthropologist's métier based on the triad of looking, listening, writing that, thanked by the exercise of epistemological reflection, brings the effectiveness of the work of the anthropologist.

We avoided the use of audio recorders, but we made use, between one and another work in the field, of micro interviews, or small elucidations and reflections, which remain archived, through "WhatsApp" technology with two board members and other members and guests.

In order to achieve these objectives, a division of labor was required. We began by reading various works carried out within motor clubs in other capital cities in the country to understand the different systems and their meanings. Not for comparative purposes, but looking to look at the different contexts and structures of other groups molded from the same historical context.

This study, very briefly, deals specifically with understanding of the place, from the production of spaces that result from appropriation by a group of common people, united around the same passion, the motorcycle, and which, in this way, promote other relations and create new places, whether permanent or temporary. 
It addresses new places and their symbols, which emerge from multi-scale scenarios of space, and which carry systems of meaning for a given social group with a set of shared values, beliefs, or other senses.

\section{Discussion}

\section{Motor clubs in America: spatial appropriation history}

Mesquita \& Maia [9] in their study about urban tribes, more specifically about the motor clubs in the city of Goiânia, its relations with that city and among the other groups constituted under the aegis of control over social public spaces, bring important summary about the origin of the motorcycle clubs, whose beginning refers to the years of 1940 in the USA.

These authors work with the hypothesis of the birth of the groups of motorcyclists there in a period of different social behaviors, that arise from the moment of a certain disenchantment of individuals in response to a society that was seen as socially exclusive.

They evidenced that the groups of motorcyclists did not necessarily intend to question the social order, but expressed, from their style, a reaction to the way of life that was established, in response to a social condition that did not satisfy them.

According to Marcuse [10], in a technologically developed society, based on a certain degree of social alienation and on the false idea that nothing could be lacking for the man who possessed a job, consumer goods, the illusion of autonomy, progress and freedom, comes a movement that opposes all the values that American citizens were so proud of. The Counterculture arises.

In the late 1940s, middle-class young people with high purchasing power and free time engaged in a horror memory of the recent war and subjected to the catastrophic possibilities of the Cold War, endowed with a liberal education that ensured the capacity for expression and criticism, began to question American society. Santos [11] states:

"It is not surprising that counterculture has emerged within American society, for it is precisely here that the technocratic society, managed by technical specialists and its scientific models, has reached the peak of its development, forcing the young person to adapt rapidly to a mechanical reality, arid and devoid of any creative impulse. With this, the counterculture became the most important expression of this group of young people who sought to "drop out" of the standards established by that society, to build an alternative world with its own 'culture'.

Such adolescents became known as 'rebels without a cause', as they criticized society and established culture by raising their own ideals of homeland, family, marriage, sexual conduct, and the environment. The cinema endorsed the behavior of those young people who exhibited a posture of confrontation with the adult world and search for their own space and freedom.

Pereira apud Calixto [12] claims that the movement questioned Western rationality, becoming stronger in the 1960s with Rock n' Roll synthesized in the figure of Elvis Presley, bringing together a young audience that was beginning to make this kind of music his discontent and rebellion. "It's called transgressed 
youth, with their gangs, motorcycles and revolts against teachers in classrooms. It is the 'rebels without cause' so portrayed, whether it be just or unjust ".

In the search for a unique and differentiated identity, they eventually propelled the consumer goods industry to the production of specific goods, which reinforced that identity, feeding new habits of food, clothing and locomotion, says Abramo [13].

In addition to these young people, driven by the availability of these specific goods, others, adult men, notably the ex-combatants of the Second War, dedicated themselves to meeting and leaving the country roads, seeking to maintain ties of friendship made during the conflict, transforming the motorcycle in a way of life based on solidarity, freedom and irreverence.

On these others, Thompson [14] shows that:

The motorcycles coming from the two great wars and modified by these motorcyclists were baptized of "Choppers", British term that has the meaning of cut, modified. This is to take advantage of the frame and/or engine of the original bike, and the other accessories are shaped by art and creativity. What emerges at that moment is the process known today as customization or customization of motorcycles. While the automobile industry produced comfortable cars and technologically modern motorcycles for locomotion of people, sports and long journeys, certain motorcyclists preferred to build their own distinctive motorcycles.

In Brazil in the mid-1940s, motorcycles were imported from factories in Italy, Germany, England and the United States for military use, which were subsequently sold for use in competitions and individuals. From the Second War the European custom of exposing military vehicles, especially motorcycles, was established at the festivities and civic parades, states Calixto [12]

Effectively approaching the possible emergence of $\mathrm{s}$ in Brazil, almost in the format we find today, Fernandes [15] argues that these associations began to expand from the 1960s onwards, with the emergence, in 1963, of Zapata MC, and in 1969 'Balaios MC', in São Paulo and Rio de Janeiro, respectively.

However, still for this author, there is an expansion in the number of $\mathrm{s}$ in the country during the transition of the 1980s and 1990s. "In 1989 is founded in São Paulo the largest Brazilian MC to this day, the 'Abutres MC'. The group has more than 6,000 registered members, in a total of 178 "factions" scattered throughout the 27 Units of the Federation". [15]

By specifically researching the $\mathrm{s}$ of Salvador, he explains that in that period the importation of motorcycles reached levels never before achieved, a fact that, reinforced by an increase in national production, culminated in the growth of motorcyclists and amateur groups throughout the country.

In Paraná, according to the website of the Magazine Motoclubes, there are 207 associations and of these, 83 only in Curitiba, place of our study. They are divided into s, Moto Friends and Brotherhoods mainly, and exhibit differentiated characteristics.

Some of them follow the ideas of those first American s, others have military characteristics, there are the most familiar or friendships, philanthropic, religious, gender-specific, mixed, those requiring specific models of motorcycles that require displacements specific ones, those involving sports.

Mesquita \& Maia [9] researching in Goiânia, clarify: 
"In this re-signification of the use of the motorcycle and the s are the associations, family s and traditional s. The Moto associations identify with those organizations of 1955 in Goiânia (Goiânia Motor Club and Motorcycle Federation of Goiânia that involves the sports); family members are groups of friends, parents and children traveling together; the traditional ones "try" to preserve the original ideal of the United States and have more severe rules for belonging to the group."

Silva [16] explains that in Goiânia the s are groups of individuals who meet as they like, walk and ride a motorcycle. As in the investigated Brotherhood, according to that author, the motorcycle is a mandatory item for entry into s.

Still according to that work, each one has its statute with rules, standards, hierarchies and quite specific representations. It clarifies, however, that the groups that carry the acronyms of $\mathrm{s}$ in their presentation are groups in general more conservative and traditional.

Explains that "Moto Groups" (MG), "Motorcycle Groups" (GM), among others, follow similar patterns, but most are groups that accept the participation of women and children, in addition to their internal rules posture, vest, color, etc., are not as rigid as those of MCs. In this way, he affirms in his work that these other formats of groups are considered by the motorcyclists as "family groups".

On this, already in 2016 and in Goiânia wrote Kleber Lopes da Silva [16] that, according to his field research, some members affirmed the facility of appearing news there, only if two or three decided to found one of them, put an image on the back and went out there.

Among other (several) criticisms that he came across through information for his ethnography, in Goiânia it is said that a lot of motorcycle club falls apart even before having status. In this case, what sustains them, and for a brief period, would be only heteronormative behavior such as rationality, violence, power and virility.

The same author explains that in Goiânia the s are groups of individuals who gather for liking, walking and traveling by motorcycle. As in the investigated Brotherhood, according to that author, the motorcycle is a mandatory item for entry into s. [16]

Hall apud Calixto [12] showed that the practice of motorcycling strengthens in the current scenario from the significant increase in the number of motorcycles sold throughout Brazil. Researching in Pernambuco states that from 1998 to August 2014, the website of the Brazilian Association of Manufacturers of Motorcycles, Mopeds, Scooters, Bicycles and Similar (Abraciclo) indicates a growth of $1,207.66 \%$ in the current fleet of two motorized wheels in that State.

Santos [11] brings the same description about the groups of motorcyclists he researched in Campina Grande, Paraíba, who, according to this author, were about 311 in the state and 33 in the city, described in his work on the creation of signs and habits in different spaces.

According to the data of their research, most of them have established their activities in promoting tourist trips on motorcycles not only by region but also by country and abroad; promoting, in addition to adventure, values such as friendship, companionship, brotherhood, cooperation and for some s linked to religion, evangelization. [11]

The difference between a and a Moto Group can be observed, in the mentioned works, is the number of members. In some of the works consulted, less than six members is not a Club. It's Group. And the Moto Group is based on 
leisure. The has social responsibilities. Brotherhood is different. It is a group of people based on rules and traditions that make it unique and whose ideology must be maintained and the members, as well as having a motorcycle lifestyle are considered "brothers by affinity".

In Curitiba we find mainly 'Moto Friends', Moto Group, and the Brotherhood, according to what was understood. Each governed by specific norms, with regiments that bring restrictions, attributions and obligations.

We therefore consider that each association has its own standards developed by the initiative of each of the groups, that these vary and depend on the world view, experiences and will of each one of its founders, advisers or members in general. In common what you see are people united around an element of cohesion - the passion for motorcycle, road and freedom.

\section{Results}

\section{The children of freedom brotherhood: their places and representations}

Of those first three idealizers, two are no longer part of the fellowship Children of Freedom. In the beginning, there were still two supporters, who also no longer have any connection with the association. In any case, their contributions and importance in the history of the Brotherhood are mentioned and recognized.

Today this association consists of 55 members who, in large majority, claim to have discovered the taste for the motorcycle very early, some still in childhood or pre-adolescence.

Naturally, it presents a Statute, whose function is to establish internal rules, establish actions and define situations as right or wrong. It has in its formation today six members of the Council of Directors that adds to another Financial Director, who are responsible for the activities of headquarters, norms of the Brotherhood and each one with its functions, but all acting always by mutual agreement.

It is evident that the Brotherhood's regulations, embodied in the statute, have contributed to its maintenance and perpetuation over time, for although the members know the rules, the statute makes clear the rights and duties of each and every one, and can be triggered in a timely manner.

There is a hierarchy that is respected by all, which does not mean that treatment with one or the other differs according to the level occupied within the Brotherhood. It is observed that the directors and members of the board of directors are related to the others in a way of proximity that does not compromise the execution of the obligations arising from that hierarchical level.

According to Cardoso [17], the place, in Anthropology, can be defined as the inscription that presents itself in a concrete and symbolic manner in space. And that inscription determines a position for all those who are destined for that place, which may be central, peripheral or intermediate. Anyway, it determines a system of values, power, or hierarchy within that place.

However, the author continues, the space understood as a place determines this value in relation to its perpetuation, that is, positions and hierarchies are necessary to make sense of that place, so that it can perpetuate itself, be intelligible.[17] 
In this way, although we are socially subject to a certain segregation between the people and the hierarchies to which they are subject, this is not visible in the Brotherhood, because in spite of occupying prestigious positions, the councilors and board of directors do not cease to belong to that group, given the mutual respect that is easily observed.

Headquarters as the place of the Brotherhood Children of Freedom, then, only exists because those positions exist and sustain it. Everyone has their work, their contribution, and their value within that place. And it's only for that reason that it exists.

Other elements that are easily observed are the symbols that permeate that universe. The headquarters, the badge and the train are the elements considered special, not only because they are important to and in any motor club, but because among Children of Freedom symbols are potentially ritual.

This is because they are cultural elements that have a symbolic communication, dispensing with words and acts, and assuming for themselves symbolic content and arrangements that show a complexity of senses and have important links with each other.

In the beginning there was no fixed seat, and the meeting point of the first members was their work places and their own residences. Today, the headquarters of the Children of Freedom is their second home, where a man can both be an individual and a group.

The territory, as well as the place, is the representation of a collective ordering of the space. Moreover, the transformation of space into place is the materialization of identity, the material construction of that identity from the record of relationships already established by these groups amongst themselves and with the totality that surrounds them.

Throughout these 22 years, the Brotherhood has had other addresses. Nevertheless, this thirst, to what it all demonstrates, is the most iconic.

Your presence commands respect. The black color of the façade and its larger symbol, the badge (Picture 2), carved and flanked by torches that are lit on Thursdays at night, give the grandeur to the entrance, which while keeping the gates open, demonstrate both strength and simplicity.

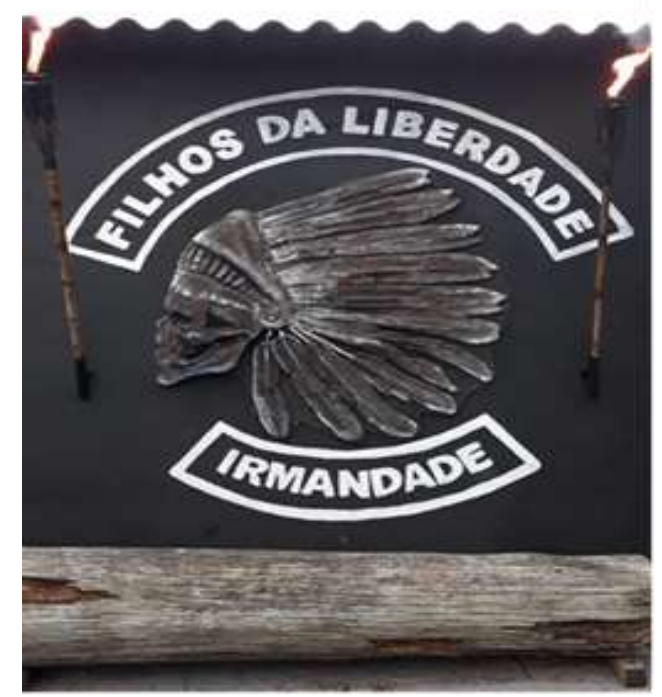

Picture 2: Façade and badge. (Source: author) 
Unlike some motorcycle riders, keeping the gates open signals that both the guests of the members and components of other Brotherhoods or s are welcome, as long as they respect the rules of the house.

Passing through the gates, one can see a spacious entrance, a long, wide and organized corridor that, because of its dimensions, can have different uses and which aims at the integration and comfort of motorcyclists, their families and friends, with banks, support for helmets, tables and chairs, strategically distributed.

It is a well-decorated and flashy space. The high, black and illuminated wall shows the evolution of the COF badge, as well as other symbols that refer to the identity of the group, as well as words that are part of the anthem, as well as the concept of piloting and motorcycling, such as traffic signs (Picture 3).

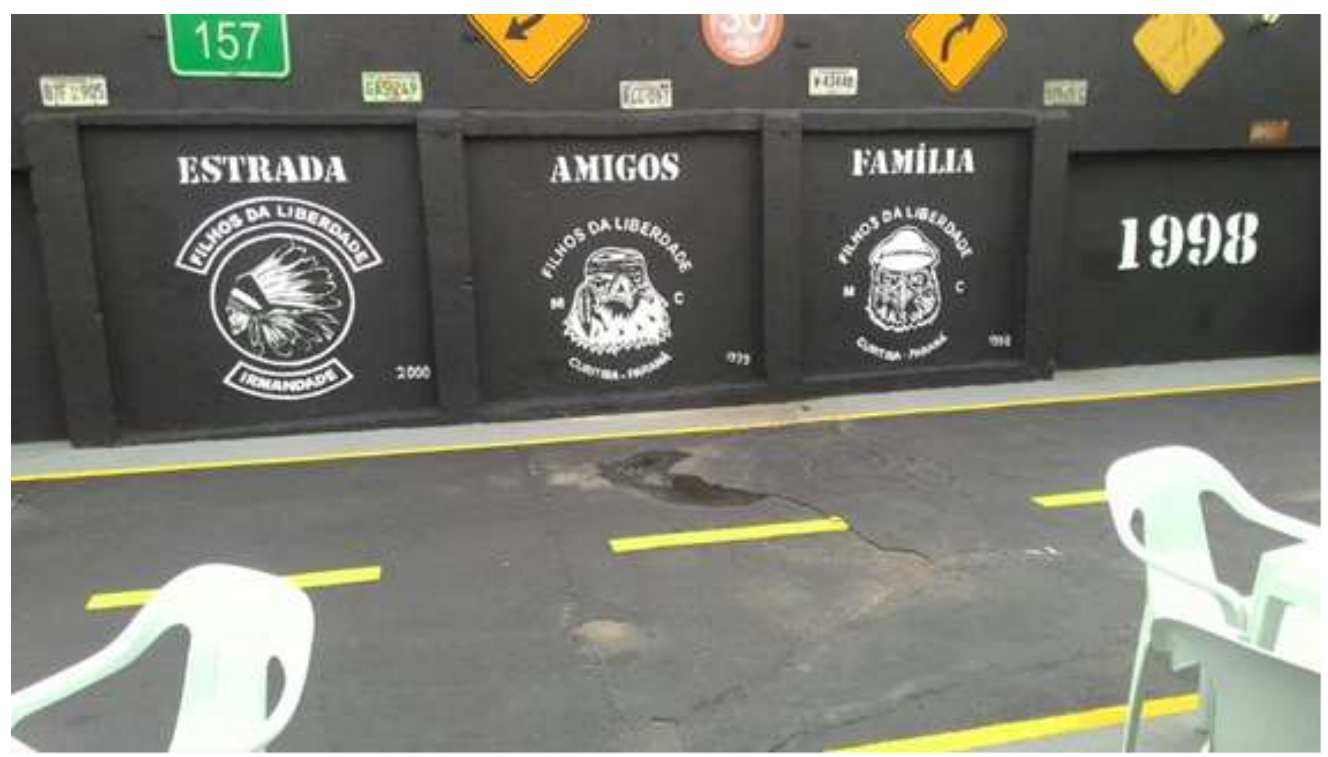

Picture 3: The entrance corridor and the greater symbols, the badge evolution and the words that symbolize the maxims of the group: "road", "friends" and "family" (Source: author).

Keeping one of the main points of independence, the COF are not linked to other groups or other flags, but maintains a space to receive in its headquarters, sporadically, members of other groups of motorcyclists, national or international that are passing through here.

In order to do so, it maintains an accommodation, organized for overnight guests who can enjoy the security and comfort of the Brotherhood. Besides the accommodation, the headquarters also has a shop that sells clothing and accessories unique to the COF and also more general, evidently referring to the concept and style of motorcycling.

Between the store space and the accommodation, there is the meeting room, where ordinarily (every two months) and extraordinarily if necessary, the councilors gather for general deliberations.

The meeting room has a large, oval table, where the centerpiece reproduces the badge, symbol of the Brotherhood due to the composition and importance of its elements. The absence of a head seat proves the equality between the councilors having all the same voting and veto power, regardless of when they started to participate in the Brotherhood. The barbecue and the kitchen complement this space. 
We arrive at the hall, which is the main part of the headquarters, because being of large dimensions comfortably houses the members of the group and their families.

The hall has wooden tables, with the carved badge, pool tables that can be used by members, sofas, male and female bathrooms, bar and a space for artistic presentations.

The entire hall is permeated with memories and objects that refer to the two decades of the Brotherhood's history. Souvenirs of trips, gifts of other groups and small and diversified pieces, each bringing its frame, adorn the place.

Other elements deserve analysis, as they all have important stories and connections with the group itself and with each one of its members. There are two icons, among all the others, that deserved special attention.

A character (Zero One) who, among other elements, symbolizes and materializes the organization of that Brotherhood. It is a stylized mannequin, a native American warrior, who in his dress, adornment and posture, channels the feeling of freedom, respect for the brothers, care for the family, bravery in relation to the protection of the territory, the kindness towards the minors and the attention to the environment where it is inserted.

The hall also contemplates a mural with the photographs of the members and, next, the photographs of the only two deceased members, never forgotten, and thus presented honestly still as components of the Brotherhood (Picture 4).

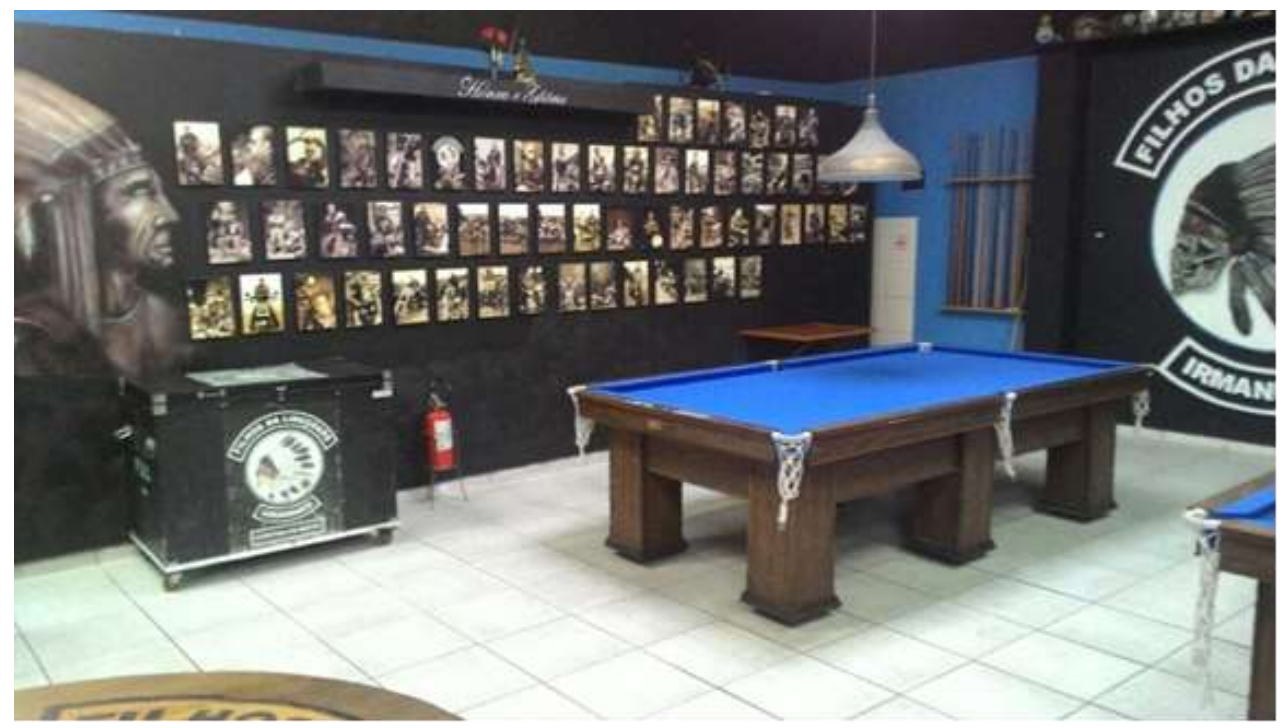

Picture 4: Main hall, bar, pool table and member's photographs: fun, fraternization and memories (Source: author)

Fortuna [5] although deals specifically with ethnic and traditional groups whose belonging is alien to the will of the individual, but tied to tradition, he argues that, rather, belonging to a group, whether religious, sports, or identity, is a choice for rational evaluation of individuals.

However, his underlying point of analysis is that even so this rational choice does not reduce the importance of values, in an ambivalence between rationality and subjectivity, affections, feelings and emotions.

This is why memories of the old place also appear as a symbol of the Brotherhood's history, such as the decoration of the bar counter, for example. It is lined with rustic wood that was part of the decoration of the old headquarters and was transferred to the current one, keeping itself in the memory of the group. 
Gregor apud Loch [18] one of the precursors of Anthropology of Space among the indigenous people of the low lands demonstrates that through a "basic ethnography of the use of space", mehináku can understand a group's social world. Applied to our study, these notions point to some similarities.

Questions of public or private, when we mention the store and accommodation in relation to the meeting room, or moral issues governing fractions of space, with the panel showing the photographs of deceased members and members, territory as something in motion, and memory from the old badges and understanding of identity from how each culture elects the notion of importance between things.

It is important for new members to understand, practice, and respect thirst by understanding their elements that are an important part of the Brotherhood's history. History is not left behind among the Sons of Freedom, just as it does not forget the deceased brothers. The most important practices within the brotherhood are friendship, respect, and fellowship.

Every Thursday night the headquarters opens its gates, starting at $18 \mathrm{~h} 30$. The frequency is great, some motorcyclists come alone, others bring friends, or come with the family. Some directly from work. Some guests mingle with them, with their own motorcycles or as croups.

The meetings at the headquarters are premised on coexistence, the maintenance of friendship, the revitalization of memories. There are regular meetings, even meetings and those with artistic presentations or special celebrations such as birthdays and the Acoustic, which happens monthly, brings artists of different styles for presentation, and always brings together many members, their families and guests.

Apparently it is one of the elements that contributes to the stability of the Brotherhood, because it brings different people linked by specific bonds: the passion for the motorcycle and respect for the group. Those men can have any profession, creed, ethnicity, political party or football team. There is their place, it is where they are the same.

Headquarters is the main meeting point, which reflects a living space, almost materializing the sense and practice of being a Child of Freedom. You see the capacity of the headquarters to be space, when it has the capacity to carry the elements that make up the identity of the in a concrete way, and where it allows the symbols, meanings and ideas of being one of the Brothers to be exposed in this space.

Everyone is very proud of thirst, and they show great care with it. In addition, they appear to be very calm about their participation, their role as a member. According to what you see, they have thirst as house and brothers as family.

This is what Magnani [19] describes as the "piece". An interposed space, which mediates the public and the private, where there is a broader sociability, even though it is not founded on family ties, but equally dense and meaningful than formal or imposed by social rules. Calixto [12] describes as "a space where motorcyclists usually practice their loyalties, where there is the sharing of codes and belongings". [12]

So, the site I show here is forged in this web of meanings, a space of relationships constructed through proximity, symbolic affectivities and subjectivities that even outside the Brotherhood headquarters still materialize and typify this "place" even outside of it. We are now dealing with the badge and the train. 
Calixto [12], in a tradition begun possibly with the motorcycle clubs formed after World War II by the American veterans, explains that it is evident the importance of the coat of arms of the components, transforming those old associations, in the then titled motor clubs of patch.

Quoting Alford and Ferriss (2007), the author states that the patch is the most important symbol and possession of a member of a motorcycle club and historically any attempt to deprive it of its use may be met with aggressive hostility. Similarly, the history of motorcycle clubs informs that members who dishonor the club should return the patch, and other symbols of belonging to those associations, such as tattoos, can be deleted. [12]

And she complements:

One of the oldest patch clubs in the world is Hell's Angels, founded in 1948 in California, formed by veterans. Declaring themselves as a group One per Cent (1\%), that "do not fit and do not care", according to Thompson (1995), the Angels also wore the "13" emblem on the vest, indicating the use of marijuana, since the number represents the position of the letter " $\mathrm{m}$ " in the alphabet.

Colored or in black and white, usually the name of the club is on top of the coat, in a semicircular sign. Below is the name of the city where the motorcycle club is located. In the middle, the coat of arms, using images, as heads of the dead, animals, and swords, arrows, knives, among others. [12]

The Badge of the Sons of Freedom Brotherhood brings many elements in its meaning, which permeate the simple sense of identification. It brings the essence of the group's values and is carried with pride on the vest of the members, on the facade of the headquarters, on the wall of the hall.

In its upper semicircle the inscription, "Children of Freedom" represents freedom as the way and regent of its actions. The contour rings of the coat of arms represent the union between the members. The bench fund has as representation the peace within the fellowship. The coat of arms displays a skull of a headdress that brings in its symbolic the freedom achieved with death, after death, the legacy of a life of struggle in defense of the territory, the family and their beliefs. The lower semicircle bears the inscription 'Brotherhood'.

The badge is reproduced on the back of the vest, on the facade of the headquarters, on the stickers of motorcycles and on the flags of the brotherhood, and is something beyond its meaning, for it represents a broader aspect of this group, revealing the essence of the fellowship and identifying those who belong to it.

The badge, and its importance, can be represented by what called multiplicity, in line with Turner [20] because although it is only one element, it is the result of an aggregate of ethical and social experiments. "Each symbolic element is related to some empirical element of experience. A single symbol represents many things at the same time, is multifarious and not univocal. Its referents are all of the same logical order but are drawn from many fields of social experience and evaluation.

The importance of the vest comes next, as the badge bearer. It is the identifying element of the motorcyclist and his or her membership in a motorcycle club or Brotherhood.

Historically it is linked to the beginning of the motorcycle clubs and symbolizes rebellion and individuality. According to Silva [16]: 
"associated by some around Korean War veterans and, by others, to the rebellious and seemingly unproductive youngsters of the 1950s (so well represented by Marlon Brando in 'The Wild'), 'Leather Folk' began by gathering people who liked to ride a motorcycle, dressed in jackets and leather pants and found in a few bars around the United States".

Proveti [21] says that early in the history of the motorcycle riders dressed in sweaters, school-aged team jackets, and garage overalls, where only a few of them displayed the name on the back of their jackets. For him, it was from the return of the combat pilots of the Second War that the practice of putting images and symbols on their jackets was established, reproducing the practice of combat.

For him, the reproduction of iconic images of American culture in jackets and in his fighter planes sent them into a universe of belonging, courage and protection. Upon returning they decided to reuse these jackets as protection and, added to their motorcycles and the freedom they brought, such as comfort and relief from post-traumatic stress. [21]

Suffering interferences of historical periods related to the motorcycling already explained in this work, the jackets became vests giving more comfort and freedom to the pilot, and they ended up earning patches with the name of the groups from the decade of 70 .

SILVA [16] also informs about the use of vests by s of Goiânia, stating that:

Clothing worn by motorcyclists in the field. When the motorcyclist is part of a MotoClube, patches are sewn, glued or "silked" on his "vest" that identifies him and places him among the other motorcyclists. Patches represent the member's hierarchical status in MotoClubes. And depending on the rules of M.C., the fabric and color of the vest are also standardized. "In addition to being worn by M.C., vests are commonly used by motorcyclists in general and by rock lovers".

Calixto [12] transcribes an interview resulting from her field work for his research at a Recife Club, about the importance of the vest:

Among motorcyclists, there is the idea that the vest is nontransferable, being his "second skin", which is especially because he is stamping the coat that identifies the club. "The vest is as personal as a toothbrush. Borrowing is a tremendous gaffe. Without it, people will not know who I am", said a motorcyclist.

The Children of Freedom vests, in addition to the badge or stripe, show other patches, with different symbols. The feathers that mark the time of affiliation to the brotherhood, each time in its color. The ax, which originally represented the seven council members, now comprised of only five components, is a type of hierarchical representation, and Malaria, a kind of patch that represents an award, awarded on merit to the members who brought important contributions to the Brotherhood or even affiliation. There is also an indication of the faction that the member belongs to.

Each of the above elements is loaded with symbols, and demonstrates various empirical elements of experience or status within the Brotherhood. They are granted in a logical order and carry with them a representation responsibility of the institution itself. 
To paraphrase Goffman [22] symbols can be seen as social information of individuals, and will confirm what other signs speak about him, completing his image. For it is through the materiality of the symbols that individuals construct the images they have of themselves.

The coat and patches obey a rigor in their colors, sizes and positions, in which they are nailed to the vests, reproducing a style different from the FDL in relation to other s and Brotherhoods.

For the others, there is a pattern, since the vests of the rump show two semicircles. The superior with the inscription "Children of Freedom" and the inferior one with the inscription of the host city, Curitiba/PR/Brazil. There is no evolution of the vest of the croup but an identification function only.

Among the Children of Freedom it is established that the entrance of new members obeys the passage through various stages, which foresee a series of obligations, all foreseen in statute. The new members are aware of the complexity of this system of admission and the importance of maintaining tradition in the name of perpetuating the Brotherhood itself. There is no differentiation in any way among those admitted.

Neither by kinship nor by friendship or by time that attends the seat on acoustic nights or on open days the family ... All are treated equally, because all will be brothers and in this way there is no, nor can there be, any kind of unfair treatment between them.

It takes a sponsor who presents them as Prospect (PP). And in this first stage the aspirant is performing various tasks within the headquarters that make him very visible, that is, activities that make it possible to exercise contact with all the members, such as attending at the barbecue or at the bar. The members perform all the tasks of the headquarters and the brothers execute them very seriously.

In this period the aspirant does not use a stripe on the back of the vest, only displays on the front of the vest a patch with the inscription "Prospect Children of Freedom" that identifies him. There is a defined minimum pass-through time from PP to "Pinned", or for other admission phases, however this minimum pass time does not guarantee the passage. Everything will depend very much on how the activities are carried out, the acceptance of the new member by the others and how he sees and respects the Brotherhood, inside and outside the headquarters, etc.

After PP, the member changes to 'Pinned'. Here he displays on the back of the vest the upper semicircle and the faction to which it belongs. Later, the Half Badge is when the member receives the coat and the rings of contour. Finally the member has the Badge Closed, with the lower semicircle.

The closing ceremony of the Badge is a rite of passage of the greatest importance. It is performed only by the counselors, in a closed and secret ceremony, in an isolated place of the other members, on a journey. This is the Brotherhood's most important ceremony and everyone is very curious about it, but no one reveals it. And out of respect no one keeps asking about her. All that is said is that it is secret and very important.

The ritual subject remains in a relatively stable state once again, and therefore has rights and obligations to others of a clearly defined and structural kind, and is expected to conform to certain customary norms and ethical standards that bind in a system of such positions. Then the so-called "baptized" member (...) In addition to giving the motorcyclist the recognition of the group and the community, the closing of a member's vest can still give him status. In 
motorcycle clubs where the hierarchy has strength, the "badged" members (with badge) present prerogatives before the others. [12]

To use the closed vest is necessary to deserve it, cannot be used by anyone. A closed-vest biker is also known in the motorcycle field as "Badged". Only the badge represents the entire image of the coat on the back of the vest. The same of the representations in the banners, stickers and other variations.

It is the representation of the identity. The difference between a badged and the others, such as the half-badge or the Prospect vary according to the time of entrance, trust, experience of road, among others, pursuant to Silva. [16]

Within the history of the Brotherhood there may have been cases of restrictions or even of a member being asked to stop attending the seat or using the badge. But if it happened it was a unique situation, or isolated cases, which are not commented by any of the members or council members.

Respondents show great reassurance regarding their participation, their role as a member, and none of them shows any kind of fear of punishment. According to what you see, they have thirst as house and brothers as family. A family that choose themselves.

If the headquarters of the Brotherhood demarcates the territory within the city, and the badge is the representation of the identity of the group inside and outside the headquarters, it is on the road that one can exercise true freedom and the sense of belonging and territoriality.

Tuma [23] argue, "the guiding principles of choices are what make man free. The problem is in the passion in motorcycle travel, choose which few do". They explain, for motorcyclists, it is not enough to own a motorcycle or to drive in the city, because "you have to be on the road, to see a landscape that makes sense to them: any landscape in the world cut by a road, it's the perfect landscape".

In addition, complement:

Motorcycle events are motivated by the integration of those who enjoy motorcycles, by exhibitionism, which is the possibility of "showing" to others their machine or the distance traveled to be in that event, by buying and selling exclusive products and, by the journey itself, to "take the road" on its motorcycles, to have the pleasure and the feeling of freedom. Motorcycle events have a greater repercussion among their specific audience, who are scheduled to participate in these meetings in advance and travel great distances to reach the final destination, the event. [23]

Luz [24] has divided these meetings into two specific categories, Events and Motorcycle Events. Those of s are generally linked to the s, has as characteristic to add smaller number of people to be more restricted. They are events that have as purpose moments of meeting, conversations, relaxation, exchanges between s.

The Motorcycle Events are considered motorcycling in general, usually performed in larger and open spaces (Convention Centers, Racetracks, Expositions Parks and Public Squares) due to the large number of participants.

The members of the Brotherhood Children of Freedom, in addition to traveling to events here called "Motoclubism" also travel for their own leisure, a tourist town or a place that seeks to enjoy the landscape and nature.

Alone, in a double or in a Train with many members, is the moment of leaving the group to the outer space, delimiting the territory outside the seat, represented by the badge in the vests and the flag of the Brotherhood. 
Another very influential dimension in Fortune's thinking [5] appears when he addresses the "momentary and circumstantial, spatially located identities" that are appropriate for the subjects. Assuming once again a critical tone, Fortuna demonstrates that in a society that favors movement, we should not consider the identity of the subjects only from the materiality of the place, but through these momentary identities.

The Train marks a moment of great responsibility and can be of two types among the FDL: one when the guests go directly behind the 'PP' before the Hasp and another, when invited only go behind the Hasp, in order not to compromise the security of the group.

There are three main members and the base of the Train, and at the exit, wherever it was the meeting point, the Pointer, the Medium and the Hasp, must be tuned.

It is very important to quickly follow the Pointer or Middle signs so as not to compromise the safety of the Train, which normally moves in an alternating row $(\mathrm{X})$. For this, it is necessary that the members maintain the alignment, avoiding compromising the vision and the signs that dictate the rules that must be followed, being the motorcyclist with croup or riding alone.

The appreciation for these journeys and the ritualistic behaviors confirm this subjective universe, every space on the road is strictly respected, even if there are fixed positions in motion, the exit of this position regulated by directions must be signaled, actions in space that confirm again the ritualistic character on motorcycle trips, as reported by Soares [25].

The important thing is that everyone should be aware of the signals that the Pointer and the Middle perform with their arms and hands to keep the train in order to prevent other vehicles from hitting the train or compromising its safety.

For this author, "gestures contain forces that reveal an impossible power of persuasion for the word. It puts all the senses into play, not only of those who execute it, but also of those who observe it". [25]

Usually the most experienced are the three elements that command the Train, may be the oldest or the most influential position in the Brotherhood (advisers, directors) are those who command the train. But it can also be commanded by another associate, provided that 'Closed Badge'.

The order of the train is by antiquity. The oldest in the front and following the graduation, Badge Closed, Half Badge, Striped and successively until Prospero (PP). Subsequently the guests, and lastly, a more experienced member, who is the Hasp, who makes the closing of the train.

Thus, the group is organized hierarchically inside and outside the headquarters, and the members obey this hierarchy because they know, each one, its attributions. Thus, when leaving the seat in the train, the members do not produce new spaces, but reproduce the micro territory of the headquarters, and the differences, if they appear, are suppressed by virtue of the codes and norms previously established.

When we think about this non-material place, whether at the events or in the displacements, from the hierarchical formations on the train or by the size of the vest, we say that these symbols act as the constructive materiality of the place and identity of the members of the Children of Freedom Brotherhood in these absent places.

This anchoring is linked to a symbolic materiality of the place, almost like what Benedict Anderson [26] described when he explains the imagined 
communities: symbolic or discursive materiality, which mobilizes the action of many groups and communities. Which is performative and imposes practices and rituals with effective translations on the action of the subjects, even though the place in their realization is non-existent.

In that sense, to appreciate the meaning of place in this work, we need to recognize that it translates to the materiality of this group's identity in space, albeit subjective, or relativized.

\section{Conclusion}

By linking socio-spatial practices to representations, according to Menezes [1], we can establish the connections between space organization and social organization. Considering that the representations are the basis of organizations, both spatial and social, the idea of place, in this work could be classified as a fraction of this space, linked to the representations that a particular social group defines starting from the idea that it makes of itself.

The article sought to analyze the category of place from the study of the micro-territories built by members of the motor club, from their identity and cultural arrangements, in different spaces organized by the members of the Brotherhood Children of Freedom, which we call a place.

Visibly, among the members of the Brotherhood Children of Freedom, respect for the place lies in companionship among them, in compliance with general rules, whether written or not, in the pride of colors, in the reverence to symbols, and in the acceptance of hierarchies. Family care is visible at headquarters, at everybody's participatory moment, at the organization and promotion of shared events and of long, laborious or shorter and comfortable journeys.

Thus, the Brotherhood Children of Freedom presents elements that live up to the name: the sense of freedom is perfectly perceptible in the solidarity of the weekly meetings and in the emotion of the narration of memories, deeds, and travels.

In this sense, the place, which notably has as its characteristic the materialization of identity in space and, therefore implicit the sense of anchoring and of stability, for this group can take on the sense of the emancipation provided by the movement when it makes it possible to construct and reconstruct in immaterial spaces, from identifying the subjects with it:

The transformation of undifferentiated spaces into expressive territories by assigning a name or a "brand" is a strategy of meaning that, yesterday as today, seeks to confer a sense of identity and appropriation. Whether it's the delimited spacing of national states, the popular neighborhood, or the "patch", this urbanity of proximity and intimate recognition, naming is essential to creating new places, wrote Fortuna [5]

Under the theory of Henri Lefebvre [27], we understand the headquarters of the motorcycle club, the road shift through the train, and symbolic representativeness in other spaces through the badge used in the vest, such as differential spaces, places under constant construction that materialize by means of symbols and specific social relations, informal negotiations, implicit agreements and homogeneities filled with differences. 
This article, therefore, identifies the representations and spatial appropriation that arise from memories, senses and identity symbols, and shows the construction of a universe of affectivities, which define the construction of the place for the members of the motorcycle club.

For this reason, it tries to demonstrate how this same place can be recreated starting from the demarcation of the subjects and their symbols in non-material places, in a new identity dimension.

Since any search for concepts between anthropological elements stumbles on the attribution of categories and may, therefore, forge a simplification of social processes, the observation of such facts has helped us to realize that the cultural identity of the group is not only about how the Children of Freedom Brotherhood members work the material and immaterial conditions of the place of identity, but also how that group relates to what is outside of this place.

\section{References:}

1.Menezes M. (2000) Do espaço ao lugar: Do lugar às remodelações sócio-espaciais. Horizontes Antropológicos [Internet]. [cited 2020 Aug 30];6(1) DOI https://doi.org/10.1590/S010471832000000100008. Available from: https://www.scielo.br/scielo.php?pid=S0104$71832000000100008 \&$ script $=$ sci_arttext

2.Martins CJ. (2012) Sobre duas rodas: o moto-turismo no Rio Grande do Sul [Dissertação on the Internet]. Caxias do Sul, Brasil: Universidade de Caxias do Sul; 2012 [cited 2020 Dec 14]. 155 s. Available from: https://repositorio.ucs.br/handle/11338/740 Mestrado Acadêmico em Turismo e Hospitalidade.

3.Velho G, Kuschnir K. (2003) Pesquisas urbanas: desafios do trabalho antropológico. 1st ed. Rio de Janeiro, Brasil: Jorge Zahar Editor; 3, Moura, C. P. de. Vivendo entre muros: o sonho da aldeia; p. $43-54$.

4.Uriarte UM. (2009) Produção do espaço urbano pelos homens ordinários: antropologia de dois micro-espaços na cidade de Salvador. Revista Iluminuras: Publicação Eletrônica do Banco de Imagens e Efeitos Visuais - BIEV/LAS/PPGAS/IFCH/UFRGS [Internet]. 2009 [cited 2020 Dec 14];15(36):115-134. DOI https://doi.org/10.22456/1984-1191.52637. Available from: https://www.seer.ufrgs.br/iluminuras/article/view/52637/32585

5.Fortuna C. (2012) (Micro)territorialidades: metáfora dissidente do social. Revista Terra Plural: Revista de Pós-Graduação em Geografia. [Internet]. Dec 01 [cited 2020 Dec 14];6(1):199-214. DOI 10.5212/TerraPlural.v.6i2.0001. Available from: https://estudogeral.sib.uc.pt/handle/10316/41186

6.Velho G, Kuschnir K. (2001) Mediação, cultura e política. 1st ed. Rio de Janeiro, Brasil: Aeroplano; 344 p. 1 vol. ISBN: 85-86579-17-3.

7.Segaud F. (2010) Anthropologie de l'espace: habiter, fonder, distribuer, transformer. 2nd ed. Paris: Colin; 01/06. 248 p. 1 vol. ISBN: 978-2200248154.

8. Oliveira RC de. (2017) O trabalho do antropólogo: olhar, ouvir, escrever. Revista de Antropologia: UNESP [Internet]. 2017 May 20 [cited 2020 Dec 14];39 [1]:13-37. DOI 10.2307/41616179. Available from: https://www.jstor.org/stable/41616179

9.Mesquita MEA, Maia CES. (2007) Territórios e territorialidades em Goiânia: as tribos dos es. Boletim Goiano de Geografia [Internet]. [cited 2020 Dec 14];27(1):125-142. DOI DOI: 10.5216/bgg.v27i3.3976. Available from: https://revistas.ufg.br/bgg/index

10.Marcuse H. (2014) Ideologia da sociedade industrial: o homem unidimensional. 14th rev. ed. Rio de Janeiro, Brasil: Jorge Zahar Editor; 238 p.

11.Santos SS. (2011) Tribos urbanas: apropriações e formas de uso do espaço urbano em Campina Grande - PB [Monografia on the Internet]. Campina Grande, Brasil: Universidade Estadual da Paraiba; [cited 2020 Dec 14]. $69 \quad$ s. Available from: http://dspace.bc.uepb.edu.br/jspui/bitstream/123456789/3088/1/PDF\%20-

\%20Steferson\%20Silva\%20Santos.pdf Graduação em Geografia.

12.Calixto RKF. (2015) Forjados no calor do asfalto: constituição de subjetividades de motociclistas no espaço social es no Recife [Dissertação on the Internet]. Recife, Brasil: Universidade Federal de Pernambuco; [cited 2020 Dec 14]. 107 s. Available from: https://docplayer.com.br/27204900Rebeca-kramer-da-fonseca-calixto.html Mestrado em Antropologia.

13.Abramo HW. (1994) Cenas Juvenis: Punks e Darks no Espetáculo Urbano. 1st ed. São Paulo: Editora Pagina Aberta; ISBN: 0041-8862. 
14.Thompsom HS. (2010) Hell's Angels: a strange and terrible saga. 4th ed. Porto Alegre, Brasil: L\&PM; ISBN: 978.85.254.3479-1.

15.Fernandes HS. (2016) A relação entre as identidades territoriais e a "nova urbanidade": o caso das manifestações identitárias dos grupos de motociclistas em Salvador, Bahia [Dissertação on the Internet]. Salvador, Brasil: Universidade Federal da Bahia; [cited 2020 Dec 14]. 103 s. Available from: http://repositorio.ufba.br/ri/handle/ri/19345 Mestrado em Antropologia Social.

16.Silva KL. (2016) "Isso é coisa pra macho": a construção de masculinidade nos encontros de motociclistas em Goiânia [Dissertação on the Internet]. Goiania, Brasil: Universidade Federal de Goias; [cited 2020 Dec 14]. $99 \quad$ s. Available from: http://repositorio.bc.ufg.br/tede/handle/tede/6448 Mestrado em Antropologia.

17.Cardoso CF. (2007) Repensando a construção do espaço. Revista de História Regional: Departamento de História e do Programa de Pós-Graduação em História da Universidade Estadual de Ponta Grossa [Internet]. 2007 Sep 23 [cited 2020 Dec 14];3(1) Available from: https://revistas2.uepg.br/index.php/rhr/article/view/2050

18.Loch S. (004) Arquiteturas xoklengs contemporâneas: uma introdução à antropologia do espaço na terra indígena de Ibirama [Dissertação on the Internet]. Florianópolis - Brasil: mestranda; 2004 [cited 2020 Dec 14]. 147 s. Available from: https://repositorio.ufsc.br/handle/123456789/88156 Mestrado em Antropologia Social.

19.Magnani JGC. (2003) Festa no Pedaço: cultura popular e lazer na cidade. 3rd ed. São Paulo, Brasil: Hucitec/UNESP; 192 p. ISBN: 85-271-0466-0.

20.Turner VW. (1974) O processo ritual: estrutura e antiestrutura. 1st ed. Petrópolis, Brasil: Vozes; 245 p. ISBN: 301-296-894.

21.Provetti R. (2018) A história do colete de e. Viagem de Moto.com [Internet]. Aug 09 [cited 2020 Dec 14];História:1-8. Available from: https://www.viagemdemoto.com/historia/3951-a-historia-docolete-de-moto-clube

22.Goffman E. (1981) Estigma: notas sobre a manipulação da identidade deteriorada. 4th ed. São Paulo, Brasil: LTC; 160 p. ISBN: 8521612559.

23.Tuma RL, Mesquita MEA \& Maia CES. (2016) Liberdade sob duas rodas: as espacialidades vividas pelos praticantes de Mototurismo. Ateliê Geográfico: Revista Eletrônica [Internet]. [cited 2020 Dec 14];10(1):164-182. DOI https://doi.org/10.5216/ag.v10i2.36422. Available from: https://www.revistas.ufg.br/atelie/article/view/36422

24.Luz CCR. (2009) Sobre duas rodas: emoções e consumo no motociclismo [Dissertação on the Internet]. Rio de Janeiro, Brasil: Universidade do Estado do Rio de Janeiro; [cited 2020 Dec 14]. 156 s. Available from: http://www.bdtd.uerj.br/tde_busca/arquivo.php?codArquivo=1615 Mestrado em Sociologia.

25.Soares MEAM. (2016) Idas e vindas entre as paisagens e as festas motociclísticas e motoclubistas no estado de Goiás [Tese on the Internet]. Goiânia, Brasil: Universidade Federal de Goiás; [cited 2020 Dec 14]. 251 s. Available from: http://repositorio.bc.ufg.br/tede/handle/tede/5865 Doutorado em Geografia.

26.Anderson B. (2006) Imagined Communities: Reflections on the Origins and Spread of Nationalism. London: Verso; ISBN: 1-84467-086-4.

27.Lefebvre H. (2000) La production de l'espace. Paris - França: Anthropos; 2000. ISBN: 9782717839548. 